\title{
Photographic identification and citizen science combine to reveal long distance movements of individual reef manta rays Mobula alfredi along Australia's east coast
}

\author{
Asia O. Armstrong ${ }^{1 *}$ (D) Amelia J. Armstrong ${ }^{1}$ (D), Michael B. Bennett ${ }^{1}$ (D) Anthony J. Richardson ${ }^{2,3}$ (D), \\ Kathy A. Townsend ${ }^{4}$ and Christine L. Dudgeon ${ }^{1}$ (B)
}

\begin{abstract}
Research into the movement ecology of terrestrial and marine animals is growing globally, especially for threatened species. Understanding how far an animal can move and the extent of its range can inform conservation planning and management. On the east coast of Australia, reef manta rays Mobula alfredi are the subject of a photographic identification study, Project Manta. In June 2018, videos of reef manta rays from the SS Yongala $\left(19.31^{\circ} \mathrm{S}, 147.62^{\circ} \mathrm{E}\right)$, were submitted to the Project Manta east coast sightings database. The videos were of two individuals previously identified from North Stradbroke Island $\left(27.42^{\circ} \mathrm{S}, 153.55^{\circ} \mathrm{E}\right)$, about $1150 \mathrm{~km}$ to the south of the SS Yongala. This represents the greatest point-to-point distance travelled by individual $M$. afredi and extends the latitudinal range for this sub-population on the east coast. This study highlights that citizen science input can provide valuable data to address knowledge gaps in the distribution and population range of marine species. Knowledge of the 1000+ km range movement potential of individual $M$. alfredi, highlights the possibility that regional sub-populations may span jurisdictional zones of more countries than previously considered likely, complicating conservation management of this species.
\end{abstract}

Keywords: Home range, Animal movement, Population connectivity, Photo-ID, Great barrier reef, Elasmobranch, Dispersal capacity

\section{Introduction}

Knowledge of the movement ecology of species, and how far individuals move is important for understanding population structure and for conservation planning and management (Hays et al. 2016). The movements and distributions of non-commercial fish species are generally poorly-understood when compared to commercially important fishes, and other marine megafauna such as sea turtles (Fossette et al. 2010; Houghton et al. 2006; Schofield et al. 2013), cetaceans (Christal and Whitehead 1997; Williams et al. 2009; Cheney et al. 2013) and seabirds (Hennicke and Weimerskirch 2014; Ludynia et al. 2012; Péron et al. 2013).

\footnotetext{
* Correspondence: a.armstrong2@uq.edu.au

${ }^{1}$ School of Biomedical Sciences, The University of Queensland, St Lucia, QLD 4072, Australia

Full list of author information is available at the end of the article
}

The reef manta ray Mobula alfredi, is a large, pelagic elasmobranch (disc width up to $5 \mathrm{~m}$ ) found in tropical and subtropical waters of the Indo-Pacific Oceans, often associated with coastlines and coral or rocky reef habitats. This species displays aggregative behaviours at predictable locations that have provided good opportunities to investigate their biology and ecology (Marshall et al. 2011; Dewar et al. 2008; Kitchen-Wheeler et al. 2012). The application of photographic identification (photoID) and electronic tagging has shown a relatively high degree of site fidelity to meso-scale geographical regions (Couturier et al. 2018; Braun et al. 2015; Setyawan et al. 2018). One outcome of such site fidelity, could be the formation of local sub-populations, particularly if there are barriers to interchange of individuals with adjacent populations. Currently, there is little evidence of

(C) The Author(s). 2019 Open Access This article is distributed under the terms of the Creative Commons Attribution 4.0 International License (http://creativecommons.org/licenses/by/4.0/), which permits unrestricted use, distribution, and reproduction in any medium, provided you give appropriate credit to the original author(s) and the source, provide a link to the Creative Commons license, and indicate if changes were made. The Creative Commons Public Domain Dedication waiver (http://creativecommons.org/publicdomain/zero/1.0/) applies to the data made available in this article, unless otherwise stated. 
contemporary connectivity among regions across the species' distribution (Stewart et al. 2018).

To date, the largest point-to-point movements by individual $M$. alfredi are around $650 \mathrm{~km}$, based on movements along the east coast of Australia (Couturier et al. 2014) and between atolls in the Maldives (Stevens and Peschak 2016). Several other studies have demonstrated shorter movements between locations (Table 1), and studies have yet to demonstrate movements across international boundaries (Stewart et al. 2018).

Mobula alfredi occurs around the Australian coastline in warm temperate and tropical waters, spanning $>7000$ $\mathrm{km}$ from Shark Bay, WA $\left(25.99 \mathrm{~S}, 113.79^{\circ} \mathrm{E}\right)$, across northern Australia, to the Solitary Islands, NSW (30.21 $\mathrm{S}$, $153.27^{\circ}$ E) (Armstrong unpublished data). The longest documented point-to-point movement of an individual reef manta ray from these coastlines was on the east coast, between North-West Solitary Island, NSW to Lady Elliot Island, Qld $\left(24.11^{\circ} \mathrm{S}, 152.71^{\circ} \mathrm{E}\right)$, a distance of $650 \mathrm{~km}$ (Couturier et al. 2014). This coastline is characterised by shallow continental shelf waters with rocky and coral reefs, forming semi-continuous habitat. Here, through a combination of citizen science and researcher-focused photo-ID surveys, we report on the movements of $M$. alfredi in waters along Australia's east coast and consider how the species' use of what is in effect linear suitable habitat may result in the formation of regional subpopulations.

\section{Methods}

Photo-ID is an approach that can be applied to any species whose individuals have unique skin patterns or other features that are stable over time (Marshall and Pierce 2012; Bansemer and Bennett 2008; Reisser et al. 2008; Wiirsig and Jefferson 1990). Photographs of animals can provide discrete information about individuals' locations in time and space. Each manta ray has a ventral body surface that has light and dark pigment distributed in a unique pattern, that varies in the number, size, shape, position and density of spots and patches (Marshall et al. 2011; Kitchen-Wheeler 2010). On the Australian east coast, Mobula alfredi has been the focus of a photo-ID program (Project Manta) since 2007. Images of manta rays from along the coast are submitted for inclusion in the Project Manta database by trained researchers performing repeated, intense surveys at specific locations and, more opportunistically, by citizen scientists, such as recreational SCUBA divers, snorkelers, and people within the dive industry (Dudgeon et al. 2016). Images, along with various metadata (including the date and location of image capture), are entered into a searchable database that allows the history of individual rays to be explored.

On 1 June and 29 June 2018, videos of $M$. alfredi were submitted to Project Manta by citizen scientists. Two individual reef manta rays were filmed at the wreck of the SS Yongala, a $107 \mathrm{~m}$ long, 3,364t steamer that sank in $30 \mathrm{~m}$ of water in 1911 off Townsville, Queensland $\left(19.31^{\circ} \mathrm{S}, 147.62^{\circ} \mathrm{E}\right)$. Still images of the two rays from the videos were matched against images in the Project Manta east coast sighting database. This northern site of the SS Yongala, and the site to the south (Manta Bommie, North Stradbroke Island) where the individuals had previously been seen, were used to estimate the greatest point-to-point distance moved by each ray, using the marmap package in R (Team 2013; Pante et al. 2018). This estimate excluded possible passage of manta rays through the $70 \mathrm{~km}$ long Great Sandy Strait that separates Fraser Island from the mainland, as this includes narrow and very shallow sections, and there have been no records of manta rays in the strait.

\section{Results}

As of 29 June 2018, the east coast sighting database contained verified photographic records of 1235 individual Mobula alfredi, from 6375 encounters recorded at 31

Table 1 Greatest point-to-point distances moved by individual Mobula alfredi

\begin{tabular}{|c|c|c|c|c|}
\hline Location & Species & Method & Distance (km) & Study \\
\hline East Coast, Australia & M. alfredi & Photo-ID & 650 & (Couturier et al. 2014) \\
\hline Maldives & M. alfredi & Photo-ID & 650 & (Stevens and Peschak 2016) \\
\hline East Coast Australia & M. alfredi & Satellite tag & 520 & (Jaine et al. 2014) \\
\hline Komodo NP, Indonesia & M. alfredi & Photo-ID & 450 & (Germanov and Marshall 2014) \\
\hline Japan & M. birostris ${ }^{a}$ & Photo-ID & 350 & (Homma 1997) \\
\hline Red Sea, Saudi Arabia & M. alfredi & Satellite tag & 169 & (Braun et al. 2015) \\
\hline Maldives & M. birostris ${ }^{a}$ & Photo-ID & 160 & (Kitchen-Wheeler 2008) \\
\hline Raja Ampat, Indonesia & M. alfredi & Acoustic track & 100 & (Setyawan et al. 2018) \\
\hline Hawai'i & M. alfredi & Acoustic track & 63 & (Clark 2010) \\
\hline Hawai'i & M. alfredi & Photo-ID & 40 & (Deakos et al. 2011) \\
\hline
\end{tabular}

${ }^{a}$ Indicates the species was likely to be M. alfredi, but was published as M. birostris as these papers pre-date the redescription of the former (Marshall et al. 2009) 
unique locations, between the Solitary Islands, NSW in the south, and Tijou Reef, Qld $\left(13.16^{\circ} \mathrm{S}, 143.97^{\circ} \mathrm{E}\right)$ in the north. This included 69 individuals identified from north of the SS Yongala (75 encounters), 10 individuals recorded at the SS Yongala site itself (12 encounters), and 1156 individuals from south of the wreck (6288 encounters); with no prior overlap of sightings among these locations (Fig. 1).

Citizen science images of $M$. alfredi from the SS Yongala site taken on 1 June 2018 were matched to reef manta ray individuals coded \#736 and \#1153 in the database (Figs. 2 and 3). The subsequent sighting at the SS Yongala on 29 June 2018 also matched individual \#736, an immature male (Fig. 2). This individual had been sighted 20 times before at Manta Bommie, North Stradbroke Island $\left(27.42^{\circ} \mathrm{S}, 153.55^{\circ} \mathrm{E}\right)$ between April 2013 and December 2017. Individual \#1153, a sexually mature male (Fig. 3), was previously sighted twice off North West Island $\left(23.30^{\circ} \mathrm{S}, 151.70^{\circ} \mathrm{E}\right)$ in April 2017, and once at Manta Bommie in March 2018.

Images of these two reef manta ray individuals in the database showed that they had been at Manta Bommie,
North Stradbroke Island prior to their sighting at the SS Yongala. The shortest distance between the two sighting locations, without crossing land, is $1150 \mathrm{~km}$ (Fig. 1). Manta ray \#1153 moved between these two sites within a 3-month period at a speed of at least $12.7 \mathrm{~km} \cdot \mathrm{d}^{-1}$, and manta ray \#736 within a 7-month period at a speed at least $5.5 \mathrm{~km} \cdot \mathrm{d}^{-1}$.

\section{Discussion}

The observations here extend the longest verified movement of an individual Mobula alfredi between two locations, from $650 \mathrm{~km}$ (also from the east coast of Australia; Couturier et al. 2014) to $1150 \mathrm{~km}$. Interrogation of the east coast photo-ID database had revealed a well-defined sub-population of $M$. alfredi between the Solitary Islands in the south and the Capricorn Bunker Group in the southern Great Barrier Reef (Couturier et al. 2011). The latitudinal extent of this group of rays now extends to the SS Yongala in the north (Fig. 1).

As reef manta rays are large-bodied, pelagic rays with a wide tropical and subtropical distribution in the IndoPacific, they could potentially move vast distances.

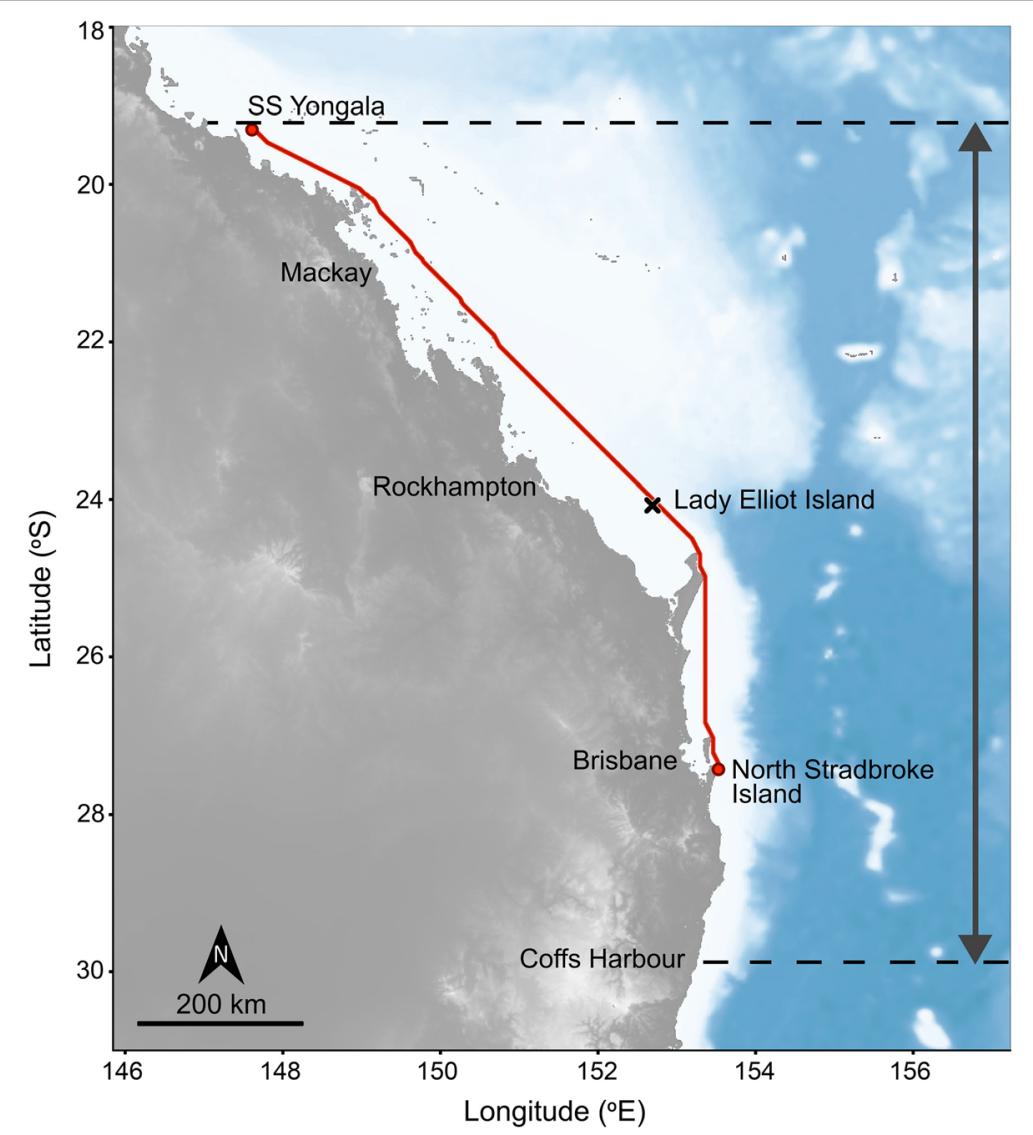

Fig. 1 The largest point-to-point movement for an individual reef manta ray Mobula alfredi. The red line presents the shortest straight-line movement between the wreck of the SS Yongala and North Stradbroke Island $(1150 \mathrm{~km})$. The arrow on the right indicates the latitudinal range of the regional sub-population of M. alfredi on this coastline as at 29 June 2018 


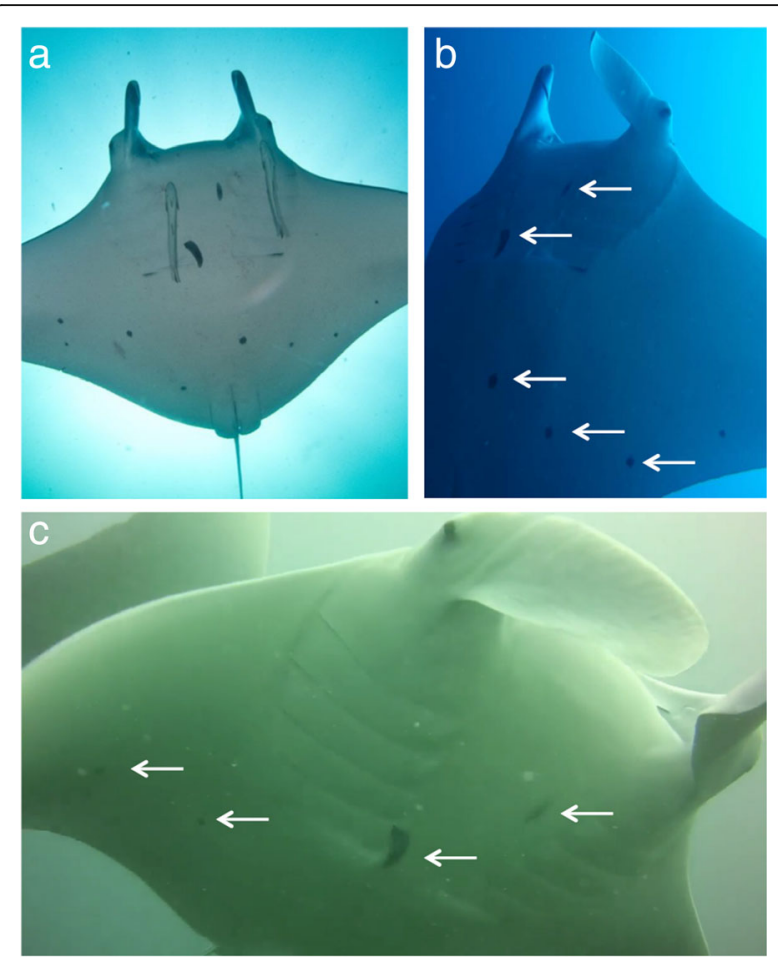

Fig. 2 Images of reef manta ray \#736, an immature male; a Reference image; and images submitted from SS Yongala on (b) 29 June 2018 and c) 1 June 2018. Arrows indicate matching spot pattern (photo credit: a John Gransbury, b Cam Risbey and c Laura Billett)

However, previous studies have documented maximum point-to-point movements of $<650 \mathrm{~km}$ (Table 1), and demonstrated high site fidelity and restricted movements (Dewar et al. 2008; Couturier et al. 2018; Setyawan et al. 2018; Kessel et al. 2017). In contrast, other pelagic elasmobranchs have longer point-to-point movements, such as the tiger shark Galeocerdo cuvier (3,500 km) (Lea et al. 2015),

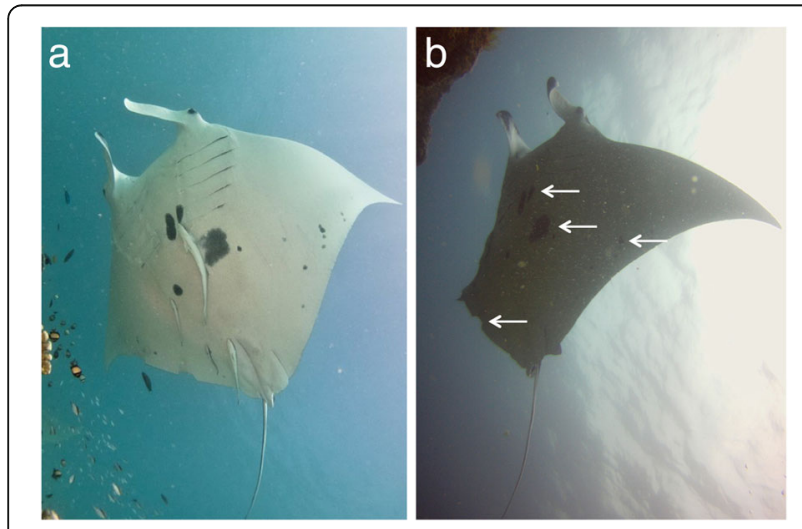

Fig. 3 Images of reef manta ray \#1153, a sexually mature male; a Reference image and $\mathbf{b}$ image submitted from SS Yongala on 1 June 2018. Arrows indicate matching spot pattern and tissue loss (likely bite wound) to right pectoral fin (photo credit: a John Gransbury and b Ariela Schnitman) blue shark Prionace glauca $(4,500 \mathrm{~km})$ (Vandeperre et al. 2014), white shark Carcharodon carcharias $(10,000 \mathrm{~km})$ (Bonfil et al. 2005), and whale shark Rhincodon typus $(15,000 \mathrm{~km})$ (Guzman et al. 2018). A satellite tagged individual of the larger manta ray species, $M$. birostris (disc width up to $7 \mathrm{~m}$ ) moved $1500 \mathrm{~km}$ between mainland Ecuador and the Galapagos Islands (Hearn et al. 2014). However, similar to the reef manta ray, the majority of studies for $M$. birostris have found this species undertakes relatively short distance point-to-point movements $(<300 \mathrm{~km})$ (Stewart et al. 2016; Graham et al. 2012).

Why $M$. alfredi appears to have relatively small directional excursions, and consequently small population ranges is uncertain. Soft barriers to dispersal, such as deep water, may play a role. For example, the volcanic islands of Hawai'i are separated by deep waters, and there is no evidence of connectivity between populations that are only $\sim 150 \mathrm{~km}$ apart (Deakos et al. 2011). However, in the Maldives, individual $M$. alfredi have transited deep waters $(\sim 2000 \mathrm{~m})$ (Stevens and Peschak 2016) and as such, depth alone does not appear to be a barrier to movement. A recent report of the first $M$. alfredi to be seen in the eastern Pacific Ocean, off the coast of Costa Rica, extends the known geographical distribution for the species (Arauz et al. 2019). It is unknown whether this individual migrated from islands $6,000 \mathrm{~km}$ to the west, or whether it is part of a previously undocumented population, as the individual had not been identified anywhere else before this sighting (it was not in the global MantaMatcher database of $\sim 9839$ individual rays) (Town et al. 2013). In the current study, the northward range extension of a regional (eastern Australian) $M$. alfredi sub-population is supported by the positive match via photo-ID of two individuals from North Stradbroke Island sighted at the SS Yongala.

This study highlights the utility of citizen science contributions to photo-ID databases. Using citizen scientists, we identified the unusual movements of two individuals from within a large population of many hundreds of $M$. alfredi. Citizen scientist involvement offers a way to increase observer effort in remote locations, such as the extensive coastal waters of northern Australia. In total, $67 \%$ of the photographic records in the Project Manta database in eastern Australia have been contributed by citizen scientists. In less populated and more remote regions, including northern QLD, up to $100 \%$ of sightings are sourced from citizen scientists (Dudgeon et al. 2016). Photo-ID databases are commonly used to track the movement of animals, including manta rays (Marshall et al. 2011; Homma 1997; Deakos et al. 2011; Kitchen-Wheeler 2010; Couturier et al. 2011), but there are several challenges associated with their use. Photo-ID is restricted to in situ observations, and the geographic and temporal cover provided by citizen scientists is unregulated, which can result in data collection bias. 
In northern Australia, the Project Manta database has opportunistic sightings of $M$. alfredi (75 encounters north of the SS Yongala, in comparison to 6300 encounters further south). The under-representation of sightings in the north is due to a lack of researcher directed surveys in this region, sparse human population, and prevalence of saltwater crocodiles Crocodylus porosus and box jellyfish Chironex fleckeri (Caldicott et al. 2005; Harrison et al. 2004). Electronic tagging offers an alternative approach to tracking animals, but generally provides short-term information and is expensive, limiting the number of animals that can be tracked (Stewart et al. 2018). However, molecular approaches based on analysis of tissue biopsies have the potential for exploring connectivity between different regions (Dudgeon et al. 2012).

\section{Conclusions}

For reef manta rays, this extended movement capability adds complexity to the management of this threatened species, as it may cross jurisdictional boundaries. In Indonesia, individuals have travelled between locations up to $\sim 450 \mathrm{~km}$ apart, moving between protected waters and regions of higher fishing risk (Germanov and Marshall 2014). Given the long-distance movement of reef manta rays observed in this study, there is likely to be increased population connectivity among regions. In northern Australia, relatively shallow coastal waters could potentially allow unobstructed movement of $M$. alfredi across international jurisdictions that offer different levels of protection and exposure to targeted fisheries. Greater harnessing of citizen science, in conjuction with international collaboration and data sharing, could provide valuable information to assess these long distance multi-jurisdiction movements.

\section{Acknowledgements}

Project Manta would like to acknowledge the contibution of the many citizen scientists, and tourism operators, whose support have improved our understanding of this species' ecology, and informed this latest finding.

\section{Authors' contributions}

$A O A, A J A, M B$ and $C D$ designed and conducted the study. $A O A, A J A$ and $K T$ collected the data. AOA, AJA, MB and CD analysed the data. AOA, AJA, MB, $A R, K T$ and $C D$ interpreted the data and compiled the manuscript. All authors read and approved the final manuscript.

\section{Funding}

This research has been funded by Australian Research Council Linkage Project (LP150100669), TG Kailis Marine Conservation Fund and Austral Fisheries. AOA and AJA are both funded by University of Queensland Research Scholarships. Funding bodies were not involved in the design of the study and collection, analysis, and interpretation of data, or in writing the manuscript.

\section{Availability of data and materials}

Data is contained in the Project Manta east coast database which is not currently available online. This information can be provided by the corresponding author upon reasonable request.
Ethics approval and consent to participate

Approval was obtained from The University of Queensland Animal Ethics Committee (SBS/319/14/ARC/EA/LEIER and SBS/342/17).

\section{Consent for publication}

Consent has been provided from contributing photographers: John Gransbury, Cam Risby, Ariela Schnitman and Laura Billett.

\section{Competing interests}

The authors declare that they have no competing interests.

\section{Author details}

${ }^{1}$ School of Biomedical Sciences, The University of Queensland, St Lucia, QLD 4072, Australia. ${ }^{2}$ Centre for Applications in Natural Resource Mathematics (CARM), School of Mathematics and Physics, The University of Queensland, St Lucia, QLD 4072, Australia. ${ }^{3}$ CSIRO Oceans and Atmosphere, Queensland Biosciences Precinct (QBP), St Lucia, QLD 4072, Australia. ${ }^{4}$ School of Science and Engineering, University of the Sunshine Coast, Hervey Bay, QLD 4655, Australia.

Received: 23 April 2019 Accepted: 15 July 2019

Published online: 22 July 2019

\section{References}

Arauz R, Chávez EJ, Hoyos-Padilla EM, Marshall AD. First record of the reef manta ray, Mobula alfredi, from the eastern Pacific. Mar Biodivers Rec. 2019;12(1):3.

Bansemer CS, Bennett MB. Multi-year validation of photographic identification of grey nurse sharks, Carcharias taurus, and applications for non-invasive conservation research. Mar Freshw Res. 2008;59(4):322-31.

Bonfil R, Meÿer M, Scholl MC, Johnson R, O'brien S, Oosthuizen H, et al. Transoceanic migration, spatial dynamics, and population linkages of white sharks. Science. 2005;310(5745):100-3.

Braun CD, Skomal GB, Thorrold SR, Berumen ML. Movements of the reef manta ray (Manta alfredi) in the Red Sea using satellite and acoustic telemetry. Mar Biol. 2015;162(12):2351-62.

Caldicott DG, Croser D, Manolis C, Webb G, Britton A. Crocodile attack in Australia: an analysis of its incidence and review of the pathology and management of crocodilian attacks in general. Wilderness Environ Med. 2005;16(3):143-59.

Cheney B, Thompson PM, Ingram SN, Hammond PS, Stevick PT, Durban JW, et al. Integrating multiple data sources to assess the distribution and abundance of bottlenose dolphins Tursiops truncatus in Scottish waters. Mammal Rev. 2013:43(1):71-88.

Christal J, Whitehead H. Aggregations of mature male sperm whales on the Galapagos Islands breeding ground. Mar Mamm Sci. 1997;13(1):59-69.

Clark TB. Abundance, home range, and movement patterns of manta rays (Manta alfredi, M. birostris) in Hawai'i [Ph.D.]. Ann Arbor: University of Hawai'i at Manoa; 2010.

Couturier L, Newman P, Jaine F, Bennett M, Venables W, Cagua E, et al. Variation in occupancy and habitat use of Mobula alfredi at a major aggregation site. Mar Ecol Prog Ser. 2018;599:125-45.

Couturier LIE, Dudgeon CL, Pollock KH, Jaine FRA, Bennett MB, Townsend KA, et al. Population dynamics of the reef manta ray Manta alfredi in eastern Australia. Coral Reefs. 2014;33(2):329-42.

Couturier LIE, Jaine FRA, Townsend KA, Weeks SJ, Richardson AJ, Bennett MB. Distribution, site affinity and regional movements of the manta ray, Manta alfredi (Krefft, 1868), along the east coast of Australia. Mar Freshw Res. 2011;62(6):628-37.

Deakos MH, Baker JD, Bejder L. Characteristics of a manta ray Manta alfredi population off Maui, Hawaii, and implications for management. Mar Ecol Prog Ser. 2011;429:245-60.

Dewar H, Mous P, Domeier M, Muljadi A, Pet J, Whitty J. Movements and site fidelity of the giant manta ray, Manta birostris, in the komodo Marine Park, Indonesia. Marine Biology (Berlin). 2008;155(2):121-33.

Dudgeon C, Blower D, Broderick D, Giles J, Holmes B, Kashiwagi T, et al. A review of the application of molecular genetics for fisheries management and conservation of sharks and rays. J Fish Biol. 2012;80(5):1789-843.

Dudgeon CL, Bansemer C, Armstrong AO, Armstrong AJ, Bennett MB, Bowden D, et al. The role of citizen science photographic identification in understanding marine megafauna populations in Moreton Bay. Proceedings of the Moreton Bay and Catchments Forum 1-3 November 2016; in press. 
Fossette S, Hobson VJ, Girard C, Calmettes B, Gaspar P, Georges J-Y, et al. Spatio-temporal foraging patterns of a giant zooplanktivore, the leatherback turtle. J Mar Syst. 2010;81(3):225-34.

Germanov ES, Marshall AD. Running the gauntlet: regional movement patterns of Manta alfredi through a complex of parks and fisheries. PLoS One. 2014;9(10):e110071.

Graham RT, Witt MJ, Castellanos DW, Remolina F, Maxwell S, Godley BJ, et al. Satellite tracking of Manta rays highlights challenges to their conservation. PLoS One. 2012;7(5):e36834 1-6.

Guzman HM, Gomez CG, Hearn A, Eckert SA. Longest recorded trans-Pacific migration of a whale shark (Rhincodon typus). Mar Biodivers Rec. 2018;11(1):8.

Harrison SL, Leggat PA, Fenner PJ, Durrheim DN, Swinbourne AL. Reported knowledge, perceptions, and behavior of tourists and North Queensland residents at risk of contact with jellyfish that cause the "Irukandji syndrome". Wilderness Environ Med. 2004;15(1):4-10.

Hays GC, Ferreira LC, Sequeira AM, Meekan MG, Duarte CM, Bailey H, et al. Key questions in marine megafauna movement ecology. Trends Ecol Evol. 2016;31(6):463-75.

Hearn AR, Acuna D, Ketchum JT, Penaherrera C, Green J, Marshall A, et al. Elasmobranchs of the Galapagos marine reserve. The Galapagos Marine Reserve: Springer; 2014. p. 23-59.

Hennicke JC, Weimerskirch H. Coping with variable and oligotrophic tropical waters: foraging behaviour and flexibility of the Abbott's booby Papasula abbotti. Mar Ecol Prog Ser. 2014;499:259-73.

Homma K, Maruyama T, Itoh T, Ishihara H, Uchida S. Biology of the manta ray, Manta birostris Walbaum, in the Indo- Pacific, pp 209-216. In: Seret B, Sire JY (eds) Indo-Pacific fish biology: proceedings of the fifth international conference on Indo-Pacific fishes, Noumea, 1997. Ichthyological Society of France, France. 1999.

Houghton JDR, Doyle TK, Wilson MW, Davenport J, Hays GC. Jellyfish aggregations and leatherback turtle foraging patterns in a temperate coastal environment. Ecology. 2006;87(8):1967-72.

Jaine FRA, Rohner CA, Weeks SJ, Couturier LIE, Bennett MB, Townsend KA, et al. Movements and habitat use of reef manta rays off eastern Australia: offshore excursions, deep diving and eddy affinity revealed by satellite telemetry. Mar Ecol Prog Ser. 2014;510:73-86.

Kessel ST, Elamin NA, Yurkowski DJ, Chekchak T, Walter RP, Klaus R, et al. Conservation of reef manta rays (Manta alfredi) in a UNESCO world heritage site: large-scale island development or sustainable tourism? PLoS One. 2017;12(10):e0185419.

Kitchen-Wheeler A, editor. Migration behaviour of the giant manta (Manta birostris) in the Central Maldives Atolls, Joint Meeting of Ichthyologists and herpetologists. Montreal: Conadad; 2008.

Kitchen-Wheeler A-M. Visual identification of individual manta ray (Manta alfredi) in the Maldives Islands, Western Indian Ocean. Mar Biol Res. 2010;6(4):351-63.

Kitchen-Wheeler A-M, Ari C, Edwards AJ. Population estimates of Alfred mantas (Manta alfredi) in Central Maldives atolls: north male, Ari and baa. Environ Biol Fish. 2012;93(4):557-75

Lea JS, Wetherbee BM, Queiroz N, Burnie N, Aming C, Sousa LL, et al. Repeated, long-distance migrations by a philopatric predator targeting highly contrasting ecosystems. Sci Rep. 2015;5:11202.

Ludynia K, Kemper J, Roux J-P. The Namibian islands' marine protected area: using seabird tracking data to define boundaries and assess their adequacy. Biol Conserv. 2012;156(0):136-45.

Marshall A, Pierce S. The use and abuse of photographic identification in sharks and rays. J Fish Biol. 2012;80(5):1361-79.

Marshall AD, Compagno LJV, Bennett MB. Redescription of the genus Manta with resurrection of Manta alfredi (Krefft, 1868) (Chondrichthyes; Myliobatoidei: Mobulidae). Zootaxa. 2009;2301:1-28

Marshall AD, Dudgeon CL, Bennett MB. Size and structure of a photographically identified population of manta rays Manta alfredi in southern Mozambique. Marine Biology (Berlin). 2011;158(5):1111-24.

Pante E, Simon-Bouhet B, Irisson J-O, Simon-Bouhet MB, Imports D. Package 'marmap'; 2018

Péron C, Grémillet D, Prudor A, Pettex E, Saraux C, Soriano-Redondo A, et al. Importance of coastal marine protected areas for the conservation of pelagic seabirds: the case of vulnerable yelkouan shearwaters in the Mediterranean Sea. Biol Conserv. 2013;168(0):210-21.
Reisser J, Proietti M, Kinas P, Sazima I. Photographic identification of sea turtles: method description and validation, with an estimation of tag loss. Endanger Species Res. 2008;5(1):73-82.

Schofield G, Scott R, Dimadi A, Fossette S, Katselidis KA, Koutsoubas D, et al. Evidence-based marine protected area planning for a highly mobile endangered marine vertebrate. Biol Conserv. 2013;161(0):101-9.

Setyawan E, Sianipar AB, Erdmann MV, Fischer AM, Haddy JA, Beale CS, et al. Site fidelity and movement patterns of reef manta rays (Mobula alfredi): Mobulidae using passive acoustic telemetry in northern Raja Ampat, Indonesia. Nat Conserv Res. 2018;3(4):1-15.

Stevens G, Peschak TP. Manta: secret life of devil rays: save our Seas Foundation; 2016.

Stewart JD, Beale CS, Fernando D, Sianipar AB, Burton RS, Semmens BX, et al. Spatial ecology and conservation of Manta birostris in the indo-Pacific. Biol Conserv. 2016:200:178-83.

Stewart JD, FRA J, Armstrong AJ, Armstrong AO, Bennett MB, Burgess KB, et al. Research Priorities to Support Effective Manta and Devil Ray Conservation. Front Mar Sci. 2018;5(314). https://doi.org/10.3389/fmars.2018.00314.

Team RC. R: a language and environment for statistical computing; 2013.

Town C, Marshall A, Sethasathien N. Manta matcher: automated photographic identification of manta rays using keypoint features. Ecol Evol. 2013;3(7):1902-14.

Vandeperre F, Aires-da-Silva A, Fontes J, Santos M, Santos RS, Afonso P. Movements of blue sharks (Prionace glauca) across their life history. PLoS One. 2014;9(8):e103538.

Wiirsig B, Jefferson TA. Methods of photo-identification for small cetaceans. Individual recognition of cetaceans: Use of photo identification and other techniques to estimate population parameters; 1990. p. 43-51.

Williams R, Lusseau D, Hammond PS. The role of social aggregations and protected areas in killer whale conservation: the mixed blessing of critical habitat. Biol Conserv. 2009;142(4):709-19.

\section{Publisher's Note}

Springer Nature remains neutral with regard to jurisdictional claims in published maps and institutional affiliations.

Ready to submit your research? Choose BMC and benefit from

- fast, convenient online submission

- thorough peer review by experienced researchers in your field

- rapid publication on acceptance

- support for research data, including large and complex data types

- gold Open Access which fosters wider collaboration and increased citations

- maximum visibility for your research: over $100 \mathrm{M}$ website views per year

At $\mathrm{BMC}$, research is always in progress.

Learn more biomedcentral.com/submissions 